\title{
PEMBANGUNAN BERTAHAP SISTEM HUKUM KOMUNITAS ASEAN
}

\author{
Melda Kamil Ariadno, ${ }^{1}$ Yusuf Ausiandra, ${ }^{2}$ Lila Pratiwi, ${ }^{3}$ Aditya Nuriya \\ Sholikhah $^{4}$
}

\begin{abstract}
This research would examine the potential gradual establishment of the Association of Southeast Asian Nations (ASEAN) Community Law system. With the application of ASEAN Charter, ASEAN is officially attributed with legal personality. In its growing development towards a community located in Southeast Asia, political cooperation has been channeled by the Roadmap for an ASEAN Community 2009-2015. However, ASEAN law system has not developed anestablished law system. Therefore, the research would observe the more succeeded international organizations i.e. World Trade Organization (WTO) and European Union (EU) in terms of the structure of the agreement, the structure of the organization and the structure of the dispute settlement. This research would strive to discover the distinction between ASEAN, EU and WTO. Subsequently, lessons-learned would help to define regional policies in order to develop an effective and efficient ASEAN law system.
\end{abstract}

Keywords: ASEAN, ASEAN community, EU, WTO, the legal system of the ASEAN community

\begin{abstract}
Abstrak
Penelitian ini mengkaji potensi pembentukan secara bertahap dari sistem hukum masyarakat ASEAN. Merujuk pada penerapan Piagam ASEAN, ASEAN secara resmi mempunyai legal personality. Dalam perkembangannya untuk menuju masyarakat Asia Tenggara, kerjasama politik telah dilaksanakan melalui Roadmap for an ASEAN Community 2009-2015. Namun, sistem hukum ASEAN belum berkembang dan terbentuk menjadi suatu sistem hukum mapan. Karena itu maka, penelitian ini mencoba untuk mengkaji kesuksesan dari

1 Melda Kamil Ariadno adalah salah seorang pengajar senior bidang Hukum Internasional di Fakultas Hukum Universitas Indonesia. Beliau juga merupakan ketua lembaga Djokosoetono Research Center dan Lembaga Pengkajian Hukum Internasional di fakultas yang bersangkutan. Alamat kontak penulisan artikel ini, pada: meldakamil@gmail.com. Indonesia.

2 Yusuf Ausiandra adalah mahasiswa pascasarjana Fakultas Hukum Universitas

${ }^{3}$ Lila Pratiwi adalah mahasiswa pascasarjana Fakultas Hukum Universitas Indonesia.

${ }^{4}$ Aditya Nuriya Sholikhah adalah mahasiswa pascasarjana Fakultas Hukum Universitas Indonesia.
\end{abstract}


beberapa organisasi internasional seperti, WTO dan Uni Eropa dalam membentuk struktur perjanjian internasional, struktur organisasi, dan struktur penyelesaian sengketa. Disamping itu penelitian ini mencoba untuk menganalisa perbedaan antara ASEAN, Uni Eropa dan WTO yang selanjutnya mengambil pelajaran dari pengalaman organisasi lain yang dapat membantu dalam menentukan kebijakan untuk membangun sistem hukum ASEAN yang efisien dan efektif.

Kata kunci: ASEAN, komunitas ASEAN, EU, WTO, sistem hukum masyarakat $A S E A N$

\section{Latar Belakang}

Perang dingin antara US dengan USSR yang terjadi di tahun 1960-an menjadi salah satu faktor pendorong berdirinya kerjasama regional ASEAN, untuk membendung komunisme di wilayah asia tenggara. ${ }^{5}$ Melalui ASEAN diharapkan mampu menstabilkan wilayah regional dari perang dan ketidakpastian politis, dengan kata lain ASEAN bertujuan untuk menegakkan cita-cita perdamaian, kebebasan, keadilan sosial dan kesejahteraan ekonomi melalui kerja sama.

Sejak tahun 1947, Negara-negara Asia Tenggara telah memulai berbagai inisiatif untuk membentuk kerjasama regional. Diawali pada tahun 1963, dimana ketegangan situasi politik mendorong Filipina, Indonesia dan Malaysia membentuk organisasi regional yang dinamakan Maphilindo. ${ }^{6}$ Namun organisasi tersebut gagal. Namun, Maphilindo memberikan pelajaran bagi pembentukan ASEAN yang pada akhirnya terwujud pada 8 Agustus 1967. Menteri Luar Negeri Indonesia, Malaysia, Filipina, Singapore dan Thailand menandatanngani Deklarasi ASEAN.

Di Bidang Ekonomi, Perubahan iklim ekonomi internasional yaitu jumlah populasi 590 juta membuat negara-negara Asia Tenggara menjadi tujuan para investor untuk melalukan investasi. Tercatat US\$ 39.6 milyar foreign direct investment (FDI) masuk di 10 negara anggota ASEAN di tahun 2009. Nilai eksport ASEAN di tahun 2009 mencapai US\$ 810.5 juta dan import sebesar US\$ 726.3 juta, total nilai perdagangan ASEAN yaitu USS 1.5 triliun di tahun 2009. ${ }^{7}$ Nilai perdagangan Negara ASEAN tersebut membuat ASEAN menjadi kekuatan ekonomi dunia yang signifikan.

Selain itu, adanya kekuatan ekonomi baru di Asia yaitu India dan China membuat ASEAN harus meningkatkan daya saing di tingkat ASIA. Adanya krisis ekonomi yang melanda Negara Asia Tenggara juga merupakan factor

${ }^{5}$ Loffelholz, Martin and Danilo A. Arao, The Asean Guide A Journalit's Handbook to Regional Integration in Southeast ASIA, GIZ: International for Journalism, 2010, hal. 38.

${ }^{6}$ Ibid., hal. 21.

${ }^{7}$ Loffelholz, Martin and Danilo A. Arao, Ibid., hal. 49. 
yang mempercepat proses integrasi di bidang ekonomi. Kondisi sosial-budaya masyarakat ASEAN sangat beragam sehingga mendorong pencarian identitas bersama dan membangun sebuah masyarakat yang sejahtera dan saling perduli melalui suatu kerjasama dibidang sosial budaya.

Keteguhan niat Negara anggota ASEAN untuk menuju suatu komunitas ASEAN diwujudkan dalam pembuatan The Declaration of ASEAN Concord II yang mengukuhkan kerjasama yang lebih dalam melalui community building melalui Blue Print di ketiga pilar. Tiga Pilar komunitas ASEAN yaitu Pilar Politik-Keamanan, Pilar Ekonomi, dan Pilar Sosial Budaya. Kerjasama yang dibangun berdasarkan dengan melalui tiga pilar komunitas ASEAN tersebut diharapkan membentuk hubungan saling ketergantungan dan terkait yang merupakan anjuran untuk memastikan tercapainya tujuan persatuan (unity). ${ }^{8}$ Adapun 3 pilar komunitas ASEAN, yaitu:

\section{Komunitas Politik-Keamanan}

Komunitas politik-Keamanan ASEAN telah dimuali lebih dari 4 dekade yang lalu melalui kerjasama dan solidaritas yang erat antar anggota ASEAN. ${ }^{9}$ Melalui Blueprint Komunitas Politik-keamanan yang dipayungi oleh Piagam ASEAN tersebut dibangnlah ASEAN Security Community Plan Action, the Vientiane Action Programme (VAP), dan berbagai keputusan yang relevan yang dibuat oleh berbagai Badan Sektoral ASEAN.

Dengan adanya Komunitas Politik-Keamanan ASEAN dapat membawa kerjasama Politik dan keamanan ASEAN ke tingkat yang lebih tinggi. Komunitas Politik-Keamanan ASEAN akan memastikan bahwa masyarakat dan negara anggota ASEAN hidup damai berdampingan atntara yang satu dengan yang lainnya serta dengan dunia pada umumnya dalam lingkungan yang demokratis dan harmonis. Melalui adanya Komunitas Politik-Keamanan ASEANini diharapakan dapat tercapai: ${ }^{10}$

a. Komunitas yang berdasarkan atas hukum dengan norma dan nilai bersama;

b. Wilayah yang kohesif, damai dengan dengan tanggung jawab bersama dalam kerjasama keamanan;

c. Wilayah yang dinamis berpandangan kedepan dalam meningkatkan integrasi dan intedependen dunia.

${ }^{8}<$ www.asean.org>, diakses pada tanggal 10 Juni 2012.

${ }^{9}$ Roadmap for ASEAN Community, hal. 5 .

${ }^{10}$ Ibid., hal. 6. 


\section{Komunitas Ekonomi ASEAN}

Komunitas Ekonomi ASEAN dalam mencapai ASEAN Vision 2020 melandaskan pada kepentingan negara anggota ASEAN untuk integrasi ekonomi yang mendalam dan luas dengan jangka waktu yang jelas. Melalui KOmunitas Ekonomi ASEAN dibangunlah suatu pasar tunggal dan production base yang membuat ASEAN lebih dinamis dan kopetitif dengan mekanisme baru dan tindakan yang memperkuat implementasi inisiasi ekonomi yang sudah ada; mempercepat integrasi regional pada sektor-sektor prioritas; memfasilitasi perpindahan business person, buruh yang memiliki keahlian dan bertalenta; dan memperkuat mekanisme institusional ASEAN. Melalui adanya Komunitas Ekonomi ASEAN diharapkan tercapai: ${ }^{11}$

a. Suatu pasar bebas dan basis produksi;

b. Sebuah kawasan ekonomi yang kompetitif;

c. Sebuah wilayah yang memiliki pembangunan ekonomi yang setara;

d. Wilayah yang sepenuhnya terintegrasi kedalam ekonomi global.

Sebuah pasar tungal dan basis produksi harus memenihu 5 elemen sebagai berikut:

a. Free flow terhadap barang;

b. Free flow terhadap jasa;

c. Free flow terhadap investasi;

d. Free flow aterhadap modal;

e. Free flow terhadap buruh yang memiliki skill.

Selain itu juga komponen yang harus masuk ialah integrasi sektor yang prioritas, panngan dan kehutanan.

\section{Komunitas Sosial Budaya ASEAN}

Tujuan utama Komunitas Sosial Budaya ASEAN adalah peoplecentered dan tanggung jawab sosial dengan pandangan untuk mencapai solidaritas dan kesatuan diantara negara-negara dan masyarakat ASEAN melalui identitas bersama dan membangun masyarakat yang saling peduli dan berbagi yang inklusif dan harmonis dimana tercapai kesejahteraan masyarakat.

Dengan adanya Komunitas Sosial-Budaya ASEAN diharapkan tercapai: $^{12}$

a. Pembangunan manusia;

b. Perlindungan dan kesejahteraan masyarakat;

c. Hal-hak dan keadilan sosial

\footnotetext{
${ }^{11}$ Ibid., hal. 32.

${ }^{12}$ Ibid., hal. 68.
} 
d. Memastikan keberlanjutan lingkungan

e. Membangun identitas ASEAN

f. Mempersempit jarak atas tingkat pembangunan.

Dalam mencapai tujuan untuk menjadikan ASEAN sebagai sebuah komuniti melalui tiga pilar ASEAN tersebut diatas maka dibuatlah suatu Piagam ASEAN yang di tanda tangani pada November 2007 dan berlaku efektif di tahun 2008. Ditandatanganinya Piagam ini memberikan personalitas hukum pada organisasi ASEAN dan menjadikan asean menjadi organisasi yang berdasarkan atas hukum (rule based organization). Piagam ASEAN memberikan personalitas hukum pada ASEAN.

Adanya Piagam ASEAN membuat adanya pernahan dalam struktur kelembagaan, penyelesaian sengketa dan bagaimana hukum di bentuk di ASEAN. Kesemua hal tersbut dilakukan dalam rangka Pembanguanan ASEAN untuk terintegrasi lebih dalam menju sebuah komuitas ASEAN.

Namun demikian ASEAN sebagai rule based organization mengalami kendala dalam implementasi dan perkembangan struktur perjanjian, kelembagaan dan penyelesaian sengketanya. ASEAN masih mengaut system organisasi internasional klasik dimana kedaulatan negara masih sangat dijunjung tinggi oleh masing-masing negara anggota. Dilain pihak WTO merupakan suatu komunitas ekonomi sedangkan Uni Eropa merupakan organisasi supranasional yang keduanya memiliki system hukum yang efektif dan efisien.

Dalam rangka membentuk system hukum ASEAN yang efektif dan efisien maka diperlukan suatu pembangunan bertahap terhadap system hukum komunitas ASEAN. Hal tersebut dapat dilakukan melalui adopsi system hukum dari WTO dan Uni Eropa.

Hal ini dapat dilakukan dengan melakukan studi komparatif sistem pembangunan hukum yang dilihat dari sejarah pembentukan kelembagaan dan sistem penyelesaian sengketa yang mengarah pada perkembangan ketiga organisasi internasional tersebut, sehingga dapat dirumuskan arah pembangunan hukum ASEAN menuju integrasi yang lebih dalam. Kedua faktor diambil sebagai dasar analisis perbandingan dikarenakan perkembangan suatu organisasi sangat dipengaruhi oleh sejarah pembentukan kelembagaan, serta sistem penyelesaian sengketa yang digunakan untuk dapat mencapai tujuan pembentukan masingmasing organisasi tersebut.

\section{Mekanisme Pembentukan Hukum dan Kelembagaan}

\section{ASEAN}

Sebagai sebuah organisasi antar pemerintah, maka otoritas tertinggi dalam organisasi ialah pertemuan kepala negara/pemerintahan negara anggota ASEAN yang disebut sebagai ASEAN Summit. Sebagai 
lembaga yang memiliki otoritas tertinggi maka ASEAN Sumit memiliki otoritas sebagai pembuat kebijakan (policy making), pengambil keputusan atas isu-isu utama yang menyangkut realisasi tujuan-tujuan ASEAN, pengambil keputusan atas hal-hal pokok yang menjadi kepentingan Negara-negara anggota dan segala isu yang dirujuk kepadanya. ${ }^{13}$ ASEAN Summit dalam mengoordinasikan pelaksanaan perjanjian-perjanjian dan keputusan-keputusannya dilakukan oleh ASEAN Coordinating Council. Pelaksanaan kebijakan yang dilakukan ASEAN Coordinating Council berkoordinasikan dengan Dewan-Dewan Komunitas ASEAN. Sehingga dapat dikatakan bahwa wewenang penuh dalam pembuat hukum terdapat apada ASEAN Summit.

Metode pengambilan keputusan yang dijadikan sumber hukum di ASEAN terdiri dari konsultasi dan konsensus sebagaimana tercantum dalam Pasal 7 ayat (2) huruf e dan Pasal 20 Piagam ASEAN. Metode konsensus merupakan konsep politik dimana kesepakatan semua pihak menjadi titik tolak dari pengambilan keputusan. ${ }^{14}$ Apabila dihubungkan dengan konsep hukum maka konsesus atau kesepakatan merupakan syarat mutlak dalam pengambilan keputusan berdasarkan suara bulat. Hal tersebut menunjukkan ASEAN menganut bentuk hubungan antar negara interetatique yang bertumpu kuat pada prinsip kedaulatan penuh negara anggota.

Di dalam Piagam ASEAN dijelaskan mengenai organ pokok dan masing-masing peran serta tanggung jawabnya. Piagam ASEAN mendiskusikan mandate berbagai organ tanpa merinci secara detail, dengan maksud memberikan organ-organ tersebut fleksibilitas untuk tumbuh, berkembang, mencapai disiplin dan tujuan organisasional yang belum tercapai. ${ }^{15}$

Table. Institusi-institusi Pembentukan Hukum ASEAN dan Pelaksananya

\begin{tabular}{|l|l|l|}
\hline ASEAN Summit & $\begin{array}{l}\text { Otoritas tertinggi pembentuk kebijakan di ASEAN, } \\
\text { terdiri dari kepala negara/pemerintahan negara } \\
\text { anggota. }\end{array}$ \\
\hline ASEAN Coordinating & Pelaksana Kebijakan ASEAN, terdiri dari para \\
\hline
\end{tabular}

${ }^{13}$ Pasal 2 (b) Piagam ASEAN.

14 Sri Setianingsih Suwardi, "Pengantar Hukum Organisasi Internasional", cetakan pertama, (Depok: Penerbit Universitas Indonesia, tanpa tahun), hal. 169.

${ }^{15}$ M. Kahler, "Legalization as Strategy: The Asia-Pacific case" (2000) 54 Int'l Org. 54 (Lihat lebih lanjut, E. Solingen, "The Genesis, Design and Effects of Regional Institutions: Lesson from East Asia and the Middle East", (2008) 52 Int'l Stud. Q. 261. Dalam Eugene K.B. Tan, "The ASEAN Charter as "Legs to Go Places": Ideational Norms and Pragmatic Legalism in Community Building in Souteast Asia, Singapore Year Book of Internasional Law, ASEAN Feature, 2008, hal. 8. 


\begin{tabular}{|l|l|}
\hline Council & Menteri Luar Negeri negara anggota ASEAN \\
\hline ASEAN Community & $\begin{array}{l}\text { Berkoordinasi dengan ASEAN Coordinating Council } \\
\text { untuk melaksanakan kebijakan pada masing-masing } \\
\text { pilang (Politik-keamanan, Ekonomi, Sosial-Budaya) }\end{array}$ \\
\hline $\begin{array}{l}\text { Committee of } \\
\text { Permanent } \\
\text { Representatives to } \\
\text { ASEAN (CPR) }\end{array}$ & $\begin{array}{l}\text { Berkerjasama dengan Sekretaris Jendral ASEAN } \\
\text { untuk mempercepat dalam pembuatan keputusan }\end{array}$ \\
\hline $\begin{array}{l}\text { ASEAN Secretariat } \\
\text { ASEC) }\end{array}$ & $\begin{array}{l}\text { Bertanggung jawab untuk mengkoordinasikan dan } \\
\text { melaksanakan kebijakan, kegiatan dan aktivitas } \\
\text { ASEAN }\end{array}$ \\
\hline $\begin{array}{l}\text { National Secretariats } \\
\text { of ASEAN }\end{array}$ & $\begin{array}{l}\text { Bertujuan melaksanakan kegiatan ASEAN pada } \\
\text { tingkat nasional. }\end{array}$ \\
\hline
\end{tabular}

Selain itu masih terdapat institusi ASEAN yang lain yaitu Badan HAM ASEAN dan Yayasan ASEAN. Badan Hak Asasi Manusia ASEAN ini dijelaskan dalam pasal 14 Piagam ASEAN. Selaras dengan tujuan-tujuan dan prinsip-prinsip Piagam ASEAN terkait dengan kemajuan dan perlindungan hak-hak asasi dan kebebasan fundamental, ASEAN wajib membentuk badan hak asasi manusia ASEAN. Untuk mengimplementasikan Pasal 14 Piagam ASEAN, maka pada tahun 2009 dibentuklah ASEAN Intergovernmental Commission on Human Rights (AICHR). AICHR berdasarkan Piagam ASEAN, berfungsi menegakkan, melindungi membentuk dan meningkatkan standar hak asasi manusia dan bertindak sebagai sebuah saluran untuk membangun kerjasama di bidang hak asasi manusia.

dilihat berdasarkan term of referencenya, AICHR hanya merupakan badan konsultasi dan masih tidak jelas kewenangannya. Selain itu dengan adanya prinsip non-interfensi dan konsensus menjadikan AICHR menjadi badan yang tidak 'tidak memiliki gigi'. ${ }^{16} \mathrm{Hal}$ tersebut dikarenakan, berdasarkan Pasal 14 ayat (2) Piagam ASEAN diatur bahwa term of reference AICHR ditentukan oleh Perteman para Menteri Luar Negeri ASEAN. Hal tersebut akan menghambat penegakan HAM di ASEAN, karena negara anggota ASEAN sangat sensitive terhadap isu HAM di masing-masing negaranya dan terdapat keenganan bagi setiap anggota

${ }^{16}$ Lihat PAsal 14 ayat (2) Piagam ASEAN. 
ASEAN bila masalah HAM tersebut dicampuri (interfere) oleh negara lain.

Enggannya negara anggota menegakkan hak asasi manusia juga dikarena adanya perbedaan kondisi sosial-politik dan budaya. Negara anggota ASEAN secara umum masih terpengaruh dengan definisi hak asasi manusia sebagaimana tertuang dalam United Nations' Universal Declaration of Human Right. Dimana para Menteri Luar Negeri ASEAN menginterpretasikan HAM sesuai dengan konteks local. ${ }^{17}$ Di ASEAN sendiri terdapat ketimpangan perkembangan HAM antara yang satu dengan anggota yang lain. Indonesia sudah sangat jauh dalam menegakkan HAM bahkan Indonesia merupakan negara yang mengusuklan dibentuknya HAM ASEAN. Namun demikian masih banyak negara-negra yang masih terbatas mengakui dan melindungi HAM khususnya CMLV. Untuk itu universalisasi HAM masihlah banyak mengalami kendala, perlu adanya adaptasi dan perkembangan perlahan untuk mearah penegakan HAM sepenuhnya. ${ }^{18}$

\section{Uni Eropa}

Perjanjian-perjanjian Uni Eropa yang terdahulu hingga perjanjian terbaru kini (Treaty of Lisbon 2009) menghimpun berbagi peraturan dan asas yang selain mengatur mengenai pembentukan sebuah ekonomi regional juga turut membentuk struktur institusional dan sistem hukum sui generis. Susunan institusi-institusi ini bertugas menegakkan dan memperlancar suatu sistem hukum, sistem hukum regional Uni Eropa. Berbeda dengan susunan institusional organisasi Internasional lain, organ Uni Eropa memiliki kewenangan penuh untuk mengatur pelaksanaan dari berbagai perjanjian Uni Eropa terlepas dari kepentingan dan kehendak Negara-negara anggota. Dengan kata lain, organ-organ Uni Eropa melaksanakan kewenangan dalam kerangka kerja komunitas Uni Eropa sebagai suatu komunitas dan tidak lagi sebagai suatu forum antar Negara. Hal ini mengingat filosofi dasar keberlakukan institusional Uni Eropa yaitu organ-organ Uni Eropa telah menerima limpahan kedaulatan dari Negara-negara anggota yang berdasarkan berbagai traktat/perjanjian Uni Eropa untuk melepas sebagian kedaulatan mereka dalam regulasi dibeberapa bidang.

Uni Eropa memiliki berbagai macam organ namun hanya terdapat lima organ utama yang mendapatkan terminologi institusi (institutions) dalam traktat Uni Eropa. Kelima organ yang selanjutnya akan disebut institutions antara lain: Dewan Uni Eropa, Parlemen Eropa, Komisi Uni Eropa, Mahkamah Uni Eropa dan Lembaga Keuangan. Adapun

${ }^{17}$ Loffelholz, Martin and Danilo A. Arao, Ibid. hal 36.

${ }^{18}$ Wawancara dengan Bpk. Adijaya Jusuf,staff pengajar HukumInternasional Fakultas Hukum Universitas Indonesia, tanggal 1 November 2012. 
institutions yang menjadi fundamen utama kelembagaan Uni Eropa adalah ke-empat institutions pertama yang merupakan organ dasar dengan prinsip-prinsip yang berbeda, dalam hal kedudukan politik serta latar belakang sosiologi, namun tetap memiliki legitimasi kelembagaan yang setara. Secara filosofis, Dewan Uni Eropa mewakili kepentingan Negara Uni Eropa, Komisi Uni Eropa mewakili kepentingan komunitas Uni Eropa, Parlemen Eropa mewakili kepentingan rakyat dari Negara anggota Uni Eropa dan Mahkamah Uni Eropa merupakan benteng prinsip Negara hukum.

Formasi ke-empat kelembagaan ini dikenal dengan sebutan quadripartisme yang dimaknai sebagai integritas dari keempat lembaga tersebut sebagai landasan institusional Uni Eropa sekaligus pelopor integritas komunitas Uni Eropa. Meskipun pembagian kelembagaan ini seolah menganut pembagian kaku khas pemisahan kekuasaan yang diajarkan Montesquieu yang menurut nama secara klasik Parlemen memegang kewenangan legislasi, pemerintah mewakili eksekutif dan Mahkamah memegang kekuasaan yudikatif namun konstruksi kelembagaan Uni Eropa tidaklah demikian. kekuasaan legislatif dalam kelembagaan Uni Eropa justeu dipegang oleh Dewan meskipun kini Parlemen memiliki peran yang lebih penting dalam memberikan keputusan dalam penciptaan hukum. selain itu, kewenangan dalam bidang keuangan terbagi diantara Parlemen, Dewan dan Komisi Uni Eropa. dari segi kekuasaan, parlemen Eropa dapat menyulitkan posisi Komisi Uni Eropa namun tidak Dewan Uni Eropa. Jadi dapat ditarik garis besar, apabila dilihat dari perspektif pembagian kekuasaan khas Montesquieu, Komisi Uni Eropa dapat dikategorikan sebagai pemegang kekuasaan eksekutif, Dewan Uni Eropa menghimpun kekuasaan legislatif, eksekutif dan adminstratif pemerintahan.

Diluar institusi-institusi utama tersebut terdapat institusi yang apabila ditinjau dari segi produk legislasi sebenarnya merupakan lembaga tertinggi yakni The European Council atau Dewan Eropa. Lembaga ini lahir dari berbagai pertemuan antar kepala pemerintahan dan kepala negara dari negara-negara anggota Uni Eropa. pada Konferensi Tingkat Tinggi/KTT Paris yang diadakan tahun 1974 telah disepakati bahwa rapat antar kepala negara atau kepala pemerintahan negara-negara anggota Uni Eropa akan diadakan tiga kali dalan setahun san dinamakan sebagai The European Council. sejak itu pula, Dewan Eropa mwnjadi sebuah badan independen dari Uni Eropa (Pasal 13 TUE).

Berbeda dengan metode klasik pengambilan keputsan yang biasa digunakan dalam organisasi Internasional yang berkarakter antar Negara seperti suara bulat dan hak veto, Uni Eropa memilih mengadopsi tiga metode pengambilan keputusan. Dalam mengambil keputusan, dewan memiliki tiga metode, yakni:

(1) Mayoritas biasa;

(2) Mayaritas bersyarat;

(3) Metode suara bulat. 
Diantara metode-metode diatas, metode kedua termasuk dalam konsep pemungutan suara yang berdasarkan kekuatan pemungutan suara yang tidak setara dan bobot suara. Pengambilan keputusan berdasarkan metode mayoritas biasa dalam mekanisme pengambilan keputusan dewan hanya diperuntukan dalam keadaan tertentu. Metode pemungutan suara berdasarkan suara berbobot merupakan metode utama dalam pengambilan keputusan. Berdasarkan metode ini, pengambilan keputusan diambil berdasarkan bobot yang diberikan kepada masing-masing Negara. Bobot ini ditentukan berdasarkan criteria umum demografis, kekuatan politik, ekonomi dan batas sepakat ditentukan hingga mencapai 2/3 dari suara berbobot pada dewan. Metode ini mengalami perkembangan terutama setelah Uni Eropa mengalami kenaikan jumlah Negara anggota hingga mencapai 27 saat ini. Apabila metode mayoritas bersyarat tetap dipertahankan maka Negara-negara besar pelopor seperti Perancis dan Jerman akan kehilangan kekuatan dalam pengambilan keputusan. Negara-negara besar pelopor meminta adanya perubahan antara pilihan penambahan bobot suara mereka atau dimasukkannya tambahan criteria yang dikenal dengan "double majorite". Pilihan kedua ini mensyaratkan bahwa selain menghitung berdasarkan bobot yang telah ditentukan tetap harus ditambahkan criteria tertentu jumlah populasi Uni Eropa. Permintaan ini kerjakan dan diawasi secara mendalam oleh Konferensi Antar Negara (Conference Inter Government/CIG) 96. Pada tahap awalnya, Negara-negara anggota Uni Eropa baru menolak perubahan hingga tercapai "compromise de Ioannina", sebuah pertemuan tidak resmi antara Menteri-menteri luar negeri dari Negara-negara anggota Uni Eropa tahun 1994 di Yunani. Hasil dari pertemuan ini menghasilkan kesediaan Negara-negara kecil untuk menerima tawaran perubahan metode perhitungan. Hasilnya kini metode yang resmi berlaku dan tercantum pada Traktat Lisbon 2009. Namun sebalum metode baru diberlakukan yakni sekitar tahun 2014 atau 2017, sebuah langkah transisi diambil dengan diperkenalkannya sebuah hak menolak dari Negara minoritas yang dikenal dengan konsep "blockade minoritas". Konsep ini menentukan bahwa apabila $1 / 3$ dari Negara anggota atau $25 \%$ dari total penduduk Uni Eropa mengajukan blockade atau penolakan terhadap suatu keputusan yang sudah memenuhi criteria kesepakatan berdasarkan mekanisme baru maka keseluruhan Negara-negara anggota lainnya berkewajiban membantu mencarikan sebuah solusi atau mempengaruhi pihak yang menolak tanpa menutup kemungkinan untuk menyelesaikan melalui jalur voting.

Metode baru ini dikenal dengan mayoritas ganda yang menentukan criteria kesepakatan sebagai terdiri dari 55\% dari Negara-negara anggota Uni Eropa atau sekitar 15 dari 27 negara anggota serta $65 \%$ dari total penduduk Uni Eropa. Metode ini turut mempertahankan konsep blockade minoritas dari compromise de Ioannina yang memungkinkan Negaranegara minoritas untuk memohon revisi dari sebuah keputusan yang dicapai dewan sebagai hasil dari penerapan metode mayoritas bersyarat 
diatas. Adapun perubahan yang dibuat adalah batas minimal Negara minoritas untuk dapat menggunakan hak menolak ini adalah 4 (empat) Negara. Metode ini telah menggantikan metode ketiga (mayoritas suara bulat) dalam beberapa bidang perjanjian Uni Eropa seperti bidang pengawasan perbatasan luar, asylum, dan keimigrasian.

Metode lain yakni metode ketiga yang dikenal dengan pengambilan keputusan adalah kesepakatan bulat. Meskipun seperti disebut di atas perlahan digantikan oleh metode mayoritas berbatas dan metode mayoritas ganda, namun masih banyak bidang yang mensyaratkan keputusan diambil berdasarkan kesepakatan bulat biasanya dalam bidang konstitusional atau kuasi-konstitusional, bidang harmonisasi politik nasional, bidang politik bersama komunitas Uni Eropa. Beberapa contoh dari bidang yang masih menggunakan metode ini tercantum dalam Pasal 18, 9, 22 dan 90 Perjanjian Roma. Mengenai penunjukan atau pengangkatan dari anggota dewan dilakukan oleh masing-masing Negara anggota berdasarkan perpolitikan dan peratural internal masing-masing Negara anggota. Dengan kata lain dimungkinkan dalam sebuah pembahasan dilakukan penggantian wakil Negara anggota. Namun hal ini tidak perlu dikhawatirkan mengingat bahwa dalam melaksanakan tugasnya anggota dewan dibantu oleh sekretaris umum dan komite perwakilan tetap.

\section{WTO}

Adapun kelembagaan yang terdapat dalam WTO berjumlah sekitar 70 badan WTO. ${ }^{19}$ Namun, yang akan dibahas dalam penelitian ini hanya insitusi yang berada pada level paling tinggi, yaitu Konfernsi Tingkat Menteri, lalu pada tingkat kedua terdapat Dewan Umum, Badan Penyelesaian Sengketa dan Trade Policy Review Body, sedangkan pada tingkat paling rendah terdapat dewan-dewan khusus, komite-komite dan working parties, yang akan diulas secara lebih singkat.

Pada tingkat tertinggi terdapat Konferensi Tingkat Menteri (Ministerial Conference), yang terdiri dari wakil-wakil setingkat kabinet dari seluruh anggota WTO dan yang bersidang sekali dalam dua tahun selama beberapa hari. Konferensi Tingkat Menteri berwenang untuk memutuskan semua hal yang tercakup dalam WTO. ${ }^{20}$ Meskipun hal ini tidak jelas apakah pasal ini memiliki kewenangan yang lebih luas untuk membuat keputusan, yang secara faktanya, memungkinkan Konferensi Tingkat Menteri ini untuk mengambil keputusan yang mana dapat mengikat anggota WTO. ${ }^{21}$ Pada tingkat kedua, terdapat Dewan Umum

\footnotetext{
${ }^{19}$ Van Bossche, Peter, Ibid., hal. 117.

${ }^{20}$ Pasal IV: 1 Perjanjian WTO.

${ }^{21}$ Van Bossche, Peter, Ibid., hal. 118.
} 
(General Council) yang bertindak melaksanakan kewenangan Konferensi Tingkat Menteri sehari-hari, yang anggotanya terdiri dari para diplomat setingkat duta besar dari seluruh anggota WTO.

Adapun mekanisme pembuatan kebijakan pada WTO yang ditempuh dalam prosedur normal dapat dilakukan dengan cara konsensus. Prosedur normal pembuatan keputusan pada lembaga WTO dilakukan dengan cara konsensus, namun tidak menutup kemungkinan adanya voting. Voting dilakukan apabila consensus tidak tercapai. Dalam sistem konsensus, semua anggota mempunyai kekuatan yang sama, yang dikenal dengan istilah "one member one vote". Voting dilakukan dengan metode majority voting.

\section{Mekanisme Penyelesaian Sengketa}

\section{ASEAN}

Selain kelembagaan, mekanisme penyelesaian sengketa ASEAN juga diatur dalam Piagam ASEAN. Penyeleseain sengketa secara damai ASEAN sendiri pertama kali disebutkan dalam 1971 Declaration of the Zone of Peace, Freedom and Neutrality, yang mengakui tujuan dan maksud Perserikatan Bangsa-bangsa termasuk penyelelesaian sengketa internasional secara damai. Dan baru pada The 1976 Declaration of ASEAN Concord, negara anggota ASEAN berkomitmen untuk menyelesaiakan sengketa secara damai memalaui proses intra-regional.

Mekanisme ASEAN sendiri telah berkembang sehingga terdapat bebrapa mekanisme penyeesaian segketa secara d ASEAN. Penyelesaian sengketa menurut prinsip umum penyelesaian sengketa dalam Piagam ASEAN ialah penyelesaian sengketa menggunakan prosedur jasa baik, konsiliasi dan mediasi.

Mekanisme penyelesaian sengketa dalam instrument tertentu yang diatur dalam Piagam ASEAN ${ }^{22}$ :

1. Sengketa-sengketa yang terkait dengan instrument-instrumen ASEAN tertentu wajib diselesaikan melalui mekanisme-mekanisme dan prosedur-prosedur seperti diatur dalam instrument dimaksud

2. Sengketa-sengketa yang tidak berkenaan dengan penafsiran atau penerapan setiap instrument ASEAN wajib diselesaikan secara damai sesuai dengan TAC (Treaty of Amity and Cooperation in Southeast Asia) dan aturan-aturan pelaksananya.

3. Apabila secara khusus tidak ditentukan sebaliknya, sengketasengketa yang berkenaan dengan penafsiran atau penerapan perjanjian-perjanjian ekonomi ASEAN wajib diselesaikan sesuai dengan Protocol ASEAN tentang Enhanced Dispute Settlemet Mechanism.

\footnotetext{
${ }^{22}$ Pasal 24 Piagam ASEAN.
} 
Namun, apabila secara khusus tidak ditentukan sebaliknya, wajib dibentuk mekanisme penyelesaian sengketa yang tepat termasuk arbitrtase untuk sengketa yang timbul berkenaan dengan penafsiran atau penerapan Piagam ASEAN dan instrument-insrumen ASEAN lainnya. ${ }^{23}$ Apabila terdapat sengketa yang tidak terselesaikan maka akan dibawa ke ASEAN Summit.

Berikut mekanisme-mekanisme penyelesaian sengketa yang diatur dibawah Piagam ASEAN:

\section{a. Konsultasi}

Pihak pemohon dapat meminta konsultasi kepada pihak termohon terkait sengketa interpretasi atau pelaksanaan Piagam ASEAN atau instrument-instrumen ASEAN lainnya dan pihak termohon wajib mempertimbangkannya. ${ }^{24}$

\section{b. Jasa Baik, Mediasi dan Konsiliasi}

Para pihak yang bersengketa dapat setiap saat melakukan jasa baik, mediasi atau konsiliasi. Proses jasa baik, mediasi ataupun konsiliasi dapat dimuali dan diakhiri setiap saat. Mekanisme ini merupakan prinsip umum penyelesaian sengketa di ASEAN yang digunakan baik dalam TAC, Penyelesaian sengketa di bidang ekonomi dan intrumen khusus ASEAN maupun dalam Protocol Piagam ASEAN mengenai mekanisme penyelesaian sengketa.

\section{c. Arbitrase}

Prosedur arbitrase digunakan atas kesepakatan bersama pihak yang bersengketa atau arahan dari ASEAN Coordinating Council. Prosedur arbitrase harus sesuai dengan ketentuan Protocol serta rules of arbitration yang diatur dalam Protokol Piagam ASEAN mengenai mekanisme penyelesaian sengketa.

Penyelesaian sengketa dibidang ekonomi diatur dalam Protocol on Enhanced Dispute Settlemet Mechanism yang banyak bercermin kepada mekanisme penyelesaian sengketa yang terdapat dalam WTO. implementasi dari mekanisme Protokol ini harus didahului dengan prosedur konsultasi dan prosedur lain yang ditentukan dalam masingmasing perjanjian ekonomi bersangkutan sebelum pembentukan Panel. ${ }^{25}$ Negara anggota ASEAN diperbolehkan menggunakan forum

\footnotetext{
${ }^{23}$ Pasal 25 Piagam ASEAN.

${ }^{24}$ Pasal 5 ayat (1) Protocol to the ASEAN Charter on Dispute Settlement Mechanism 2010

${ }^{25}$ Pasal 1 ayat (1) Protocol on Enhanced Dispute Settlemet Mechanism.
} 
penyelesaian sengketa lain dari mekanisme yang terdapat dalam Protocol ini. Pilihan untuk menggunakan forum lain ini diperbolehkan sebelum salah satu pihak mengajukan permohonan kepada SEOM (Senior Economic Officials Meeting) untuk dibentuk panel dalam rangka menyelesaikan sengketa. ${ }^{26}$ Hal tersebut dikarenakan SEOM-lah yang memiliki otoritas untuk membentuk panel, mengadopsi Panel report dan Appellate body report.

Adapun mekanisme pengambilan di keputusan harus berpegang pada prinsip-psinsip ASEAN yang dikenal ASEAN Way Dalam penggunaannya ASEAN Way landasan acuan pada: ${ }^{27}$

1. Cara menyelesaikan sengketa regional;

Dalam ASEAN Way sengketa regional harus diselesaikan dengan memenuhi prinsip non-interferensi. Ide tidak ikut campur dengan masalah negara lain dan menghormati kedaulatan nasional itu dimaksudkan untuk menstabilkan situasi kelompok Negara-negara yang tergabung dalam ASEAN. Selain itu, ASEAN mengacu pada prinsip-prinsip manajemen penyelesaian sengketa informal termasuk "menekankan keutamaan self-restraint; penerapan praktek-praktek Musyawarah dan mufakat (konsultasi dan konsensus); menggunakan pihak ketiga untuk mediasi dalam menyelesaikan sengketa, dan menyetujui untuk tidak setuju ketika mengesampingkan penyelesaian konflik.

2. Sebuah proses pengambilan keputusan tertentu,

Menurut prinsip ASEAN Way, pengambilan keputusan dalam ASEAN didasarkan pada pencapaian konsensus dengan konsultasi dan membangun suatu keputusan bukan pada keputusan mayoritas.

3. Sebuah proses membangun identitas.

ASEAN Way digambarkan sebagai suatu metode yang membantu untuk membangun identitas bersama melalui siapa saja yang berpartisipasi dalam proses pengambilan keputusan.

\section{Uni Eropa}

Dalam menegakan hukum Uni Eropa konsep yang digunakan dilandasi bertumpu pada dua lembaga utama yakni Pengadilan Uni Eropa (European Court of Justice) dan kerjasama antara Pengadilan Uni Eropa dan pengadilan-pengadilan nasional. Wewenang pengadilan Uni Eropa dijabarkan dalam Pasal 19 TEU yang antara lain mengadili atas

\footnotetext{
${ }^{26}$ Pasal 1 ayat (3) Protocol on Enhanced Dispute Settlemet Mechanism.

${ }^{27}$ Loffelholz, Martin dan Danilo A.Arao, Ibid., hal.38.
} 
tindakan-tindakan yang diajukan oleh negara-negara anggota, lembagalembaga Uni Eropa atau pribadi hukum dan memberikan preliminary rulings atas permintaan pengadilan dan peradilan-peradilan negara anggota atas tafsir hukum Uni Eropa atau validitas tindakan-tindakan yang diambil lembaga-lembaga Uni Eropa.

Sebagai "penjaga hukum Uni Eropa" (guardian of the European Union law), pengadilan Uni Eropa berwenang dalam menyelesaikan sengketa yang berhubungan dengan penegakan hukum Uni Eropa. Melalui pengajuan langsung oleh negara anggota, lembaga-lembaga Uni Eropa ataupun pribadi hukum maupun pribadi kodrati (dalam keadaan khusus), pengadilan Uni Eropa dapat memberikan interpretasi yang memiliki kekuatan hukum mengikat atas tindakan negara anggota atau lembaga Uni Eropa dalam kerangka hukum Uni Eropa.

Selain itu terdapat lembaga kerjasama antara pengadilan Uni Eropa dan pengadilan serta peradilan di masing-masing negara anggota melalui mekanisme preliminary ruling. Berkat mekanisme ini, pengadilan Uni Eropa dapat memastikan bahwa negara-negara anggota akan mematuhi dan menegakan hukum Uni Eropa pada tingkat nasional masing-masing negara.

Mekanisme preliminary ruling ini dapat bersifat fakultatif atau opsional ataupun wajib. Pasal 257 TFEU menentukan bahwa pengadilan masing-masing negara anggota memiliki kewajiban untuk melakukan preliminary ruling apabila berdasarkan hukum nasional-nya putusan pengadilan tersebut tidak dapat dibantah lagi. Mekanisme ini memungkinkan pengadilan negara-negara anggota berperan aktif dalam menegakan hukum Uni Eropa dan menjaga harmonisasi dalam interpretasi hukum Uni Eropa.

Hukum regional Uni Eropa memiliki hierarki dan sumber-sumber hukum yang relatif berbeda dengan sumber-sumber hukum internasional pada umumnya. Secara hierarkis, sumber-sumber hukum sistem hukum regional Uni Eropa dapat dibagi kedalam empat bentuk yakni: ${ }^{28}$

1. Sumber-Sumber Utama (Sources primaires);

2. Hukum turunan (Sources derivees) yang terdiri dari peraturanperaturan dan reglemen yang terdapat dalam legislasi (actes) yang dibuat oleh institusi-institusi Uni Eropa dalam rangka melaksanakan traktat Uni Eropa;

3. Sumber-sumber hukum tidak tertulis yang terdiri atas prinsip-prinsip umum hukum serta yurisprudensi Mahkamah Uni Eropa.

Ketiga pembagian sumber hukum diatas dikategorikan sebagai susunan hierarkis hukum dari sistem hukum regional Uni Eropa. Di luar sumber-sumber hukum diatas, sumber-sumber hukum Uni Eropa dapat dilengkapi oleh sumber-sumber lain antara lain:

28 John Tillotson dan Nigel Foster, "Text, Cases, and Materials on European Union Law", Edisi 4. (London: Cavendish Publishing Limited, 2003), hal. 67. 
1. Hukum yang berasal dari hubungan dengan negara lain diluar komunitas Uni Eropa;

2. Hukum tambahan (droit complementaires) yang berasal dari konvensi-konvensi (kebiasaan) antar negara anggota dalam rangka melaksanakan traktat Uni Eropa.

Berikut akan diberikan penjelasan mengenai berbagai sumbersumber hukum yang telah dijabarkan diatas dalam urutan sebagai berikut:

1. Traktat Uni Eropa (terdiri atas Perjanjian pembentuk/traite fondateurs),

2. Perjanjian Internasional antara Uni Eropa dengan negara ketiga;

3. Prinsip-prinsip Umum hukum;

4. Prinsip-Prinsip Umum Hukum Komunitas Uni Eropa;

5. Hukum Turunan (terdiri atas reglements dan reglements d'application; directives; serta decisions generates et individuelles).

\section{WTO}

Dalam sistem penyelesaian sengketa WTO yang dua tingkat, panel dan tingkat banding, dengan dua lembaga yang berbeda, terdapat satu lembaga lain yang tidak masuk dalam mekanisme penyelesaian sengketa baik panel maupun banding, namun mempunyai fungsi dalam sistem penyelesaian sengketa WTO, yaitu Badan Penyelesaian Sengketa (Dispute Settlement Body). Diantara lembaga yang terlibat dalam sistem penyelesaian sengketa WTO, dapat dibedakan antara lembaga politik, Badan Penyelesaian Sengketa, dan dua lembaga independen yang berpola pengadilan, Panel Penyelesaian Sengketa yang bersifat ad hoc dan Appellate Body (Badan Banding) yang bersifat permanen. ${ }^{29}$ Perbedaan ini dilihat dari tugas dan fungsi masing-masing lembaga tersebut dalam proses penyelesaian sengketa WTO.

Badan Penyelesaian Sengketa / DSB merupakan Dewan Umum yang bertanggung jawabnya terhadap DSU melalui Badan Penyelesaian Sengketa. ${ }^{30}$ Seperti Dewan Umum, DSB terdiri dari wakil-wakil dari semua anggota WTO yang berasal dari perwakilan pemerintah. Fungsi DSB adalah melakukan administasi yang berkenaan dengan penyelesaian sengketa WTO. Dimana telah dikatakan di atas, bahwa DSB merupakan Dewan Umum yang ditugakan untuk melakukan fungi DSB tersebut. Dengan demikian, ketika Dewan Umum melakukan hal-hal yang bersifat administrasi pada sistem penyelesaian sengketa WTO, maka pada saat ini

29 Peter van den Bossche, Op. Cit., dan dapat dilihat pada $<$ http://www.wto.org/english/tratop_e/dispu_e/disp_settlement_cbt_e/c3s1p1_e.htm>, dikunjungi terakhir pada tanggal 29 Oktober 2012.

${ }^{30}$ Lihat Pasal IV. 3 Perjanjian WTO. 
Dewan Umum bersidang dan bertanggung jawab sebagai Badan Penyelesaian Sengketa.

Panel merupakan dewan ad hoc, yang dibentuk dengan tujuan untuk menimbang dan memutuskan suatu sengketa tertentu dan akan bubar ketika telah melaksanakan tugasnya. ${ }^{31}$ Pembentukan panel oleh DSB merupakan atas dasar permintaan penggugat. ${ }^{32}$

Berikut secara ringkas tabel Perbandingan sistem organisasi ASEAN, UNI EROPA dan WTO

Table. Perbandingan Uni Eropa, WTO dan ASEAN

\begin{tabular}{|c|c|c|c|}
\hline & Uni Eropa & WTO & ASEAN \\
\hline $\begin{array}{l}\text { Konsep } \\
\text { Organisasi }\end{array}$ & $\begin{array}{l}\text { Quasi- } \\
\text { supranational } \\
\text { institutions }\end{array}$ & $\begin{array}{l}\text { Re-inforced } \\
\text { multilateral } \\
\text { approach }\end{array}$ & Legal cooperation \\
\hline \multirow[t]{2}{*}{ institusi } & $\begin{array}{l}\text { Memiliki } \\
\text { wewenang ekslusif, } \\
\text { wewenang terbagi, } \\
\text { dan wewenang } \\
\text { untuk } \\
\text { mempengaruhi. } \\
\text { Kedudukan } \\
\text { institusi-institusi } \\
\text { tersebut berada } \\
\text { diatas negara } \\
\text { anggota }\end{array}$ & $\begin{array}{l}\text { Memiliki } \\
\text { wewenang namun } \\
\text { terbatas, } \\
\text { kedudukannya } \\
\text { tidak lebih tinggi } \\
\text { dari negara } \\
\text { anggota. }\end{array}$ & $\begin{array}{l}\text { Tidak terdapat suatu } \\
\text { organ dari ASEAN yang } \\
\text { berkedudukan lebih } \\
\text { tinggi dari negara-negara } \\
\text { anggota }\end{array}$ \\
\hline & Sentralisasi & Sentralisasi & Desentralisasi \\
\hline $\begin{array}{l}\text { System } \\
\text { hukum }\end{array}$ & $\begin{array}{l}\text { Institusi- } \\
\text { institusinya } \\
\text { memiliki } \\
\text { otonomitas atau } \\
\text { independensi. }\end{array}$ & $\begin{array}{l}\text { Institusi- } \\
\text { institusinya } \\
\text { memiliki } \\
\text { otonomitas atau } \\
\text { independensi } \\
\text { namun berdasarkan } \\
\text { mandat anggota. } \\
\end{array}$ & $\begin{array}{l}\text { Masih menggunakan } \\
\text { mekanisme hukum } \\
\text { diplomatic internasional, } \\
\text { pelaksanaan institusi } \\
\text { adalah perwakilan } \\
\text { negara anggota }\end{array}$ \\
\hline $\begin{array}{l}\text { Subjek } \\
\text { hukum }\end{array}$ & $\begin{array}{l}\text { Negara dan } \\
\text { warganegara } \\
\text { (sebagai individu) }\end{array}$ & $\begin{array}{l}\text { Negara, wilayah } \\
\text { kepabeanan, }\end{array}$ & Negara anggota \\
\hline \multirow[t]{2}{*}{$\begin{array}{l}\text { Mekanisme } \\
\text { pengambilan } \\
\text { keputusan } \\
\end{array}$} & $\begin{array}{l}\text { Simple majority } \\
(50+1)\end{array}$ & $\begin{array}{l}\text { Konsensus dan } \\
\text { majority voting. }\end{array}$ & Konsensus \\
\hline & $\begin{array}{l}\text { Berdasarkan } \\
\text { jumlah perwakilan }\end{array}$ & $\begin{array}{l}\text { One member one } \\
\text { vote kecuali }\end{array}$ & - \\
\hline
\end{tabular}

${ }^{31}$ Ibid.

${ }^{32}$ Pasal 6 DSU. 


\begin{tabular}{|l|l|l|l|}
\hline & $\begin{array}{l}\text { negara yang } \\
\text { terdapat } \\
\text { parlemen. di } \\
\text { vote) }\end{array}$ & $\begin{array}{r}\text { Eropa. } \\
\text { (weight }\end{array}$ & \\
\hline $\begin{array}{l}\text { Penyelesaian } \\
\text { sengketa }\end{array}$ & $\begin{array}{l}\text { European Court } \\
\text { with } \\
\text { application direct } \\
\text { embedded in } \\
\text { relation } \\
\text { national courts with }\end{array}$ & $\begin{array}{l}\text { Claim based on } \\
\text { collective interest }\end{array}$ & $\begin{array}{l}\text { Optional ad-hoc DSM } \\
\text { yet various reference to } \\
\text { arbitration and } \\
\text { international courts }\end{array}$ \\
\cline { 2 - 4 } & $\begin{array}{l}\text { Terdapat badan } \\
\text { penyelesaian } \\
\text { sengketa }\end{array}$ & $\begin{array}{l}\text { terdapat badan } \\
\text { penyelesaian } \\
\text { sengketa }\end{array}$ & $\begin{array}{l}\text { Tidak terdapat badan } \\
\text { penyelesaian sengketa }\end{array}$ \\
\cline { 2 - 4 } & $\begin{array}{l}\text { Tersentralisasi } \\
\text { Tersentralisasi }\end{array}$ & Desentralisasi \\
\hline
\end{tabular}

\section{Analisis}

Pada awalnya pembentukan ASEAN hanya merupakan sebuah policy rezim.Namun perkembangannya, dengan adanya Piagam ASEAN menjadikan ASEAN yang mulanya sebagai legal rezim dan sebagai sebuah rule-based organization. ${ }^{33}$ Piagam ASEAN ini dijadikan kerangka dasar ASEAN sebagai organisasi yang mempunyai kerangka hukum. ${ }^{34}$ Selain itu, dengan adanya Piagam ASEAN tersebut pula membuat ASEAN menjadi predictable dan reliable. Sehingga dapat dikatakan bahwa Piagam ASEAN merupakan langkah maju yang cukup signifikan untuk menjadikannya sebagai organisasi regional bagi Negara-negara di Asia Tenggara.

Dengan dibentuknya Piagam ASEAN membawa perubahan institusi dan mekanisme pengambilan keputusan yang ada dalam ASEAN.Hal ini dilihat ketika ASEAN memperkenalkan single chairmanship ASEAN dengan membentuk ASEAN Coordinating Council untuk memperluas hubungan antar anggota dalam pembentukan kebijakan. Selain itu, Piagam ASEAN juga mendirikan Committee of Permanent Representatives yang diharapkan dapat berkerja secara efektif dan berjalan harmonis dan bekerjasama dengan Sekreteriat ASEAN serta sejalan dengan ASEAN Community Councils sehingga dapat mempercepat pengambilan keputusan dan mampu mengharmonisasi dan mengakomodir kebaikan bersama masyarakat ASEAN. Adanya Piagam ASEAN juga memberikan Sekretaris Jenderal ASEAN mandate untuk mendukung pelaksanaan aturan kebijakan (rule-based implementation of policies).

\footnotetext{
${ }^{33}$ Wawancara dengan Bapak Abdul AKdir Djailani tanggal 7 November 2012.

${ }^{34}$ Wawancara dengan Bapak Adijaya Jusuf, tanggal 2 November 2012.
} 
Pengambilan keputusan di ASEAN setelah adanya Piagam ASEAN mempertegas tradisi khusus pengambilan keputusan dengan konsensus dan soft institusionalis. ${ }^{35}$ Prinsip pengambilan keputusan yang dikenal dengan ASEAN Way mengarah kepada institusinalisasi di tingkat yang rendah. Sehingga dapat dikatakan bahwa ASEAN Way merupakan sebagai tingkatan yang rendah dari elemen supranasional. ${ }^{36}$ Meskipun elemen-elemen supranasional dalam ASEAN masih lemah, beberapa institusi ASEAN telah meningkat secara bertahap sebagaimana telah dijelaskan diatas.

Meskipun telah banyak kewenangan yang diberikan kepada institusiinstitusi ASEAN, namun tetap kewenangan tersebut masih terbatas dan di'gerogoti' oleh ketentuan dalam Piagam ASEAN itu sendiri. Hal ini dapat dilihat pada Pasal 51 Piagam ASEAN, dimana secretariat ASEAN diberikan kewenangan untuk menginterpretasiakan Piagam, namun prosedur menginterpretasikan Piagam ASEAN dibatasi oleh ketentuan yang mengharuskan keputusan dari ASEAN Coordinating Council. Sebagaimana telah dijelaskan dalam BAB sebelumnya bahwa ASEAN Coordinating Council berisikan para anggota ASEAN dan mekanisme pengambilan keputusannya menggunakan system consensus. Sistem ini sama hanya seperti sistem yang dianut oleh WTO dalam mengambil keputusan, dimana lembaga WTO yaitu Ministerial Conference yang juga beranggotakan semua perwakilan Negara anggota, mempunyai kewenangan penuh untuk mengambil suara untuk membuat keputusan.

Sistem konsensus yang ada pada ASEAN yang merupakan duplikasi sistem pembentukan hukum pada WTO. Konsekuensi sistem konsensus adalah terjadinya jalan buntu untuk mencapai suatu kesapakatan. Namun, dalam perjanjian WTO mengantisipasi hal tersebut dengan diperkenankannya prosedur suara terbanyak (majority voting) sebagai upaya jalan terakhir, sehingga apabila terdapat satu anggota yang tidak sepakat, suatu keputusan dapat dicapai. Hal ini yang tidak diatur dalam ASEAN.

Hal yang berbeda dengan pengambilan keputusan yang terdapat dalam Uni Eropa yang menggunakan sistem simple majority voting. Dimana suatu keputusan dapat dikatakan sepakat ketika telah mencapai setengah plus satu dari jumlah parlemen Eropa. Sistem ini dapat juga diadopsi sebagai alternatif pembangun ASEAN dalam mekanisme pengambilan keputusan.

Selain itu, dapat dilihat pada kewenangan ketua ASEAN atau Sekretaris Jenderal ASEAN yang bertindak dalam kapasitas ex-officio, untuk menyelenggarakan jasa baik, konsiliasi dan mediasi.Namun dibatasi dengan adanya ketentuan yaitu kewenangannya yang terbatas apabila para pihak yang bersengketa memintanya.

Dilihat dari Piagam ASEAN, dapat dilihat bahwa belum ada lembaga yang bersifat supranasional, dan tidak ada sentralisasi kewenangan dalam

${ }^{35}$ Loffelholz, Martin and Danilo A. Arao, Ibid., hal 77.

36 Jurgen Haacke, ASEAN's "Diplomatic Culture: Origins, Development and Prospects", (New York: Routledge, 2003), p. 3-7 dalam ASEAN guide, hal. 7. 
lebaga pada umumnya.Piagam ASEAN memberikan banyak kewenangan sekaligus banyak pula kewenangan institusi ASEAN tersebut yang dibatasi, hal ini mencerminkan masih terdapat ke-enganan negara-negara anggota untuk memberikan sebagian kedaulatannya kepada ASEAN. ${ }^{37} \mathrm{Hal}$ tersebut membuktikan bahwa ASEAN masih berlandaskan hukum internasional klasik dimana kedaulatan negara masih sangat mendominasi. Hal yang berbeda jika dibandingkan dengan Uni Eropa, dimana secara kelembagaan Uni Eropa memiliki organ-organ yang berdasarkan traktat diberikan hak berdaulat (sovereign rights) atas bidang-bidang ekonomi ataupun bidang lain yang memiliki implikasi ekonomi. Berdasarkan hak berdaulat tersebut negara-negara Uni Eropa menundukkan diri terhadap intervensi otoritas organ-organ tersebut dalam sistem hukum nasionalnya masing-masing agar sesuai dengan traktat yang telah mereka sepakati. ${ }^{38}$

Selain itu, Piagam ASEAN dalam menjelaskan kewenangan berbagai organ tidak merincinya secara detail, dimaksudkan memberikan organ-organ tersebut fleksibilitas untuk tumbuh, berkembang, mencapai disiplin dan tujuan organisasional yang belum tercapai. ${ }^{39}$ Meskipun saat ini institusi ASEAN belum memadai untuk terciptanya suatu supranasional namun tidak menutup kemungkinan untuk menuju kearah sana meskipun masih banyak usaha dan kemauan dari anggotanya untuk mencapai suatu komunitas yang lebih terintegrasi sebagaimana yang telah dilakukan oleh Uni Eropa.

Jika dibandingkan dengan EU dan WTO, ASEAN memiliki beragam mekanisme penyelesaian sengketa yang diatur tersendiri di setiap bidangnya sebagaimana diatur dalam BAB VIII Pasal 24 dan 25 Piagam ASEAN. Dengan kata lain ASEAN tidak memiliki mekanisme penyelesaian sengketa tunggal yang tersentralisasi, berbeda dengan EU dan WTO dimana terdapat satu mekanisme dalam mekanisme penyelesaian sengketa.

Dengan adanya pengaturan mekanisme penyelesaian sengketa di dalam Piagam ASEAN tersebut memperkuat dasar ASEAN menjadi rule based organization. Namun demikian pengaturan mekanisme penyelesaian sengketa yang terdapat dalam ASEAN masih bertumpuk-tumpuk. Selain itu kewenangan yang tidak jelas akan lingkup sengket yang menjadi kewenangan suatu mekanisme penyelesaian sengketa. ${ }^{40}$ Sebagaimana dijelaskan dalam BAB

37 Hasil wawancara dengan Bpk. Abdul Kadir Djailani, Direktur Perjanjian Internasional Bidang Ekososbud Kementerian Luar Negeri Indonesia, tanggal 7 November 2012.

${ }^{38}$ Yusuf Ausiandra, Perbandingan Antara Sistem Hukum Regional Uni Eropa Dengan Kerjasama Hukum Regional ASEAN, Skripsi, Universitas Indonesia, 2011, hal. 166.

${ }^{39}$ M. Kahler, "Legalization as Strategy: The Asia-Pacific case" (2000) 54 Int'1 Org. 54 (Lihat lebih lanjut, E. Solingen, "The Genesis, Design and Effects of Regional Institutions: Lesson from East Asia and the Middle East", (2008) 52 Int'1 Stud. Q. 261. Dalam Eugene K.B. Tan, "The ASEAN Charter as "Legs to Go Places": Ideational Norms and Pragmatic Legalism in Community Building in Souteast Asia, Singapore Year Book of Internasional Law, ASEAN Feature, 2008., hal. 8. 
sebelumnya bahwa terdapat 4 mekanisme penyelesaian sengketa dalam piagam ASEAN, namun untuk menentukan sengketa menjadi lingkup mekanisme tertentu tidaklah mudah karena semuanya terangkum dalam Piagam ASEAN yang berarti berlakulah protocol mengenai penyelesaian sengketa terhadap Piagam ASEAN. Selain itu meknisme yang terdapat dalam satu Protokol dengan Protocol lainnya memiliki esensi yang sama yaitu mengutamakan penyelesaian sengketa melalui jasa baik, mediasi dan konsiliasi.

Selain itu dalam Pasal 28 Piagam ASEAN memungkinkan digunakannya mekanisme penyelesaian sengketa yang mengacu pada Pasal 33 ayat(1) Piagam PBB atau instrument hukum lainnya, yang berarti memungkinkan digunakannya menyelesaikan sengketa secara damai selain sebagaimana ditentukan dalam ASEAN.

Mekanisme penyelesaian sengketa melalui TAC juga tidak komprehensif untuk menyelesaikan legal dispute. Hal ini disebabkan penyelesaian melalui High Council sebagaimana diatur dalam TAC berisikan seluruh menteri luar negeri negara anggota ASEAN termasuk negara yang bersengketa selain itu high council ini masih bersifat politis. Adanya pihak yang bersengketa yang dalam High Council membuat sulit tercapai kesepakatan. ${ }^{41}$

Penyelesaian sengketa di bidang ekonomi merupakan penyelesaian sengketa yang paling advance di ASEAN. Jika dibandingkan dengan WTO, DSU WTO mengikat semua anggota untuk menyelesaikan hal-hal yang berkenaan dengan sengketa dalam Perjanjian WTO untuk diselesaikan pada satu forum penyeleaian sengketa, yaitu Dispute of Understanding WTO. Sehingga tidak terdapat shopping forum sebagaimana terdapat dalam ASEAN. Demikian pula halnya pada Uni Eropa yang hanya menyelesiakan sengketa pada satu mekanisme Uni Eropa.

Namun, Protocol on Enhanced Dispute Settlement Mechanism cukup baik namun tetap ada klausula yg memperbolehkan pihak yang bersengketa memilih forum lain. Dengan demikian mekanisme ini juga belum pernah digunakan oleh negara anggota ASEAN dalam menyelesaikan sengketa. Adapun factor-fator tidak digunakannya mekanisme penyelesaian sengketa di bidang ekonomi dalam ASEAN antara lain: ${ }^{42}$

1. Budaya masyarakat Asia cenderung menghindari pendekatan yang kontrontatif dan ada suatu kecendurungan untuk menggunakan jalur negosiasi dan diplomasi ketimbang jalur hukum dan institusional. Dalam

40 Hasil wawancara dengan Bpk. Abdul Kadir Djailani, Direktur Perjanjian Internasional Bidang Ekososbud Kementerian Luar Negeri Indonesia, tanggal 7 November 2012.

41 Hasil wawancara dengan Bpk. Abdul Kadir Djailani, Direktur Perjanjian Internasional Bidang Ekososbud Kementerian Luar Negeri Indonesia, tanggal 7 November 2012.

42 Paolo R. Vergano, The ASEAN Dispute Settlement Mechanism and its Role in a Rule Based Community: overview and Critical Comparison. Paper for the Asian International Economic Law Network (AIELN) Inaugural Conference. hal. 11. 
hal ini, negara-ngara anggota yang terlibat sengketa lebih memilih menggunakan alternative non-adjudicatory mechanism yang disediakan dalam Protocol on Enhanced Dispute Settlement Mechanism seperti jasa baik, konsiliasi dan mediasi. Budaya non-konfrontatif Asia ini dapat dilihat pula dalam penggunaan bahasa dalam perjanjia-perjanjian ASEAN yang cenderung menggunakan bahasa yang kooperatif ketimbang bahasa legalistik.

2. Suatu ketakutan adanya tindakan balasan dalam penggunaan mekanisme penyelesaian sengketa yang justru tidak membangun. Negara-negara anggota ASEAN mengkhawatirkan bahwa dengan penggunaan mekanisme ini akan tercipta keadaan dimana negara-negara ASEAN justru saling mencari kesalahan dan ketidaktaatan terhadap kewajiban dibawah perjanjian-perjanjian ekonomi ketimbang mencari suatu solusi bersama.

3. Tingkat integrasi ekonomi yang relative masih mda dan masih dalam proses pembentukan suatu mayrakat yang kooperatif hingga tahun 2015 dan 2020. Digunakannya mekanisme penyelesaian sengketa berdasarkan mekanisme panel dalm protocol akan berakibat kontraproduktif dan justru dekonstruktif.

Dari analisa instrument-instrumen hukumnya terlihat bahwa ASEAN melakukan transplantasi hukum dengan maksud meniru pada Uni Eropa, PBB maun WTO. ${ }^{43}$ hal ini dikuatkan oleh pendapat Bpk. Abdulkadir Djailani yang menberikan istilah 'kegenitan hukum' ASEAN.

ASEAN dalam perkembanganya menjadi sebuah komunitas menghadapi kendala-kendala yang dikarenakan: ${ }^{44}$

1. Masih belum adanya keinginan dari masing-masing negara anggota untuk transfrer of competence dimana negara menyerahkan sebagian kedaulatan pada organisasi sebagaimna yang terdapat dalam Uni Eropa;

2. Masih adanya rasa saling curiga antar sesame negara anggota ASEAN;

3. Kondisi politik yang berbeda;

4. Tingkat keberagaman kultur masyarakat ASEAN yang tinggi;

5. Komoditi perdagangan yang relatif sama;

6. Adanya perbedaan yang cukup jauh terkait pembanguan antara negara anggota.

Dari pemaparan diatas dapat terlihat bahwa ASEAN sebagai ruled based organization masih mengaut system organisasi internasional klasik dimana kedaulatan negara masih sangat dijunjung tinggi oleh masing-masing negara anggota.

${ }^{43}$ Diane A. Desierto, ASEAN's Constitutuionalization of International Law: Challenges to Evolution Under The New ASEAN Charter, Columbia Journal of Transnational Law Association, 2011. hal. 13.

${ }^{44}$ Seluruh narasumber. 
Dapat dikatakan ASEAN merupakan 'thick' version dari kontitusionalisasi, dimana dicirikan dengan desentralisasi system internasional, sudah berdirinya dan terpeliharanya internasional order yang didalamnya termasuk hak-hak dasar dan kepentigan indivdu dan komunitas yang diakui dan adanya poenyelesaian sengketa secara damai. ${ }^{45}$ Thick konstitusinalis ini memvisualisasikan hukum internasional modern, dimana organisasi kerjasama tersebut telah melaksanakan demokrasi, mengimplementasi dan mengintrepretasikan secara sempit (tetapi berpotensi meluas) norma-norma internasional sebagimana yang telah dilakukan oleh ASEAN. Hal ini mengarah pada bentuk Kantian-Hebermasian sebagaimana yang sedang dijalankan oleh Uni Eropa saat ini. Dimana bentuk ini disebut juga seabgai "thin constitusionalism" yang digambarkan organisasinya sebagai supranasional, hal ini dikuatkan oleh pendapat Bapak Abdul Kadir Jaelani.

Sehingga kurang tepat untuk membandingkan antara ASEAN dengan Uni Eropa dan WTO karena dari sejarah awal tujuan pembentukan sudah berbeda. ${ }^{46}$ ASEAN dari awal didirikan adalah untuk tujuan politis dan sampai saat ini belum ada keinginan masing-masing negara untuk membentuk suatu komunitas. Sedangkan WTO hanyalah organisasi yang memiliki ruang lingkup lebih kecil yaitu mengatur hal-hal yang berkaitan dengan perdangan internasional Meskipun dalam perjalanannya mengalami perubahan tujuan yang tidak terbatas tujuan politis melainkan meliputi tiga pilar politikkeamanan, ekonomi dan sosial budaya. Hal ini berbeda dengan Uni Erpa dan WTO yang dari awal tujuan pembentukannya adalah untuk tujuan ekonomi.

Namun demikian dalam pembangunan system hukum-nya, ASEAN dapat melihat WTO dalam pembentukan suatu komunitas sebelum pada akhirnya berkembang seperti Uni Eropa dengan konsep supranasionalnya.

Dalam perkembangan ASEAN untuk kearah konstitusionalism model Kantian-Habermasian membutuhkan waktu dan dilakukan secara bertahap. Adapun tantangan-tantangan rangka perkembangan ASEAN yang lebih terintegrasi antara lain: ${ }^{47}$

1. adanya konstitusi atau statute yang mengikat dan direct effect;

2. transpalantasi hukum dalam ASEAN;

3. standarisasi norma-norma yang universal.

Namun, Perlu banyak pertimbangan bagi ASEAN untuk melangkah kearah integrasi lebih dalam, terdapat konsekuensi-konsekuensi apabila ingin membangun komunitas ASEAN yng lebih terintegrasi mengingat kondisi masyarakat ASEAN saat ini.

\footnotetext{
${ }^{45}$ Diane A. Desiert, Ibid.

${ }^{46}$ Seluruh nara sumber.

${ }^{47}$ Ibid., hal. 1.
} 
Tabel $^{48}$

\begin{tabular}{|c|c|}
\hline Cita-cita ASEAN & Fakta yang ada di ASEAN saat ini \\
\hline $\begin{array}{l}\text { Perdamaian dan stabilita politik: tidak } \\
\text { ada perang diantara negara anggota } \\
\text { sejak } 1967\end{array}$ & $\begin{array}{l}\text { Tidak ada mekanisme-mekanisme } \\
\text { untuk menyelesaikan sengketa antara } \\
\text { negara anggota. }\end{array}$ \\
\hline $\begin{array}{l}\text { Ditingkatkannya hubungan politik } \\
\text { regional melalui pembentukan } \\
\text { kebijakan luar negeri bersama }\end{array}$ & $\begin{array}{llr}\text { Negara-negara dengan } & \text { pengaruh } \\
\text { politik yang besar dapat mendominasi } \\
\text { negara-negara } & \text { yang } & \text { pengaruh } \\
\text { politiknya lemah. } & & \end{array}$ \\
\hline $\begin{array}{l}\text { Ditingkatkannya perlindungan hukum } \\
\text { untuk warga negara ketika berpergian } \\
\text { dan bekerja }\end{array}$ & $\begin{array}{l}\text { Terdapat kontradiksi antara retorika } \\
\text { dan kenyataan. }\end{array}$ \\
\hline $\begin{array}{l}\text { Perluasan pasar untuk menrik } \\
\text { investasi asing langsung } \\
\text { direct investment) }\end{array}$ & $\begin{array}{l}\text { Beberapa negara mungkin dapat } \\
\text { memperoleh keuntungan yang lebih } \\
\text { besar dengan adanya integrasi } \\
\text { dibandingkan dengan negara anggota } \\
\text { lainnya. }\end{array}$ \\
\hline $\begin{array}{l}\text { Blok regional memiliki suara yang } \\
\text { lebih kuat dalam forum perdagangan } \\
\text { global }\end{array}$ & $\begin{array}{l}\text { Struktur yang rumit dapat } \\
\text { menyebabkan tumpang tindih dan } \\
\text { kesulitan dalam pemahamannya. }\end{array}$ \\
\hline $\begin{array}{l}\text { Mengurangi kekkuatan atas keegoisan } \\
\text { kepentingan nasional demi } \\
\text { kepentingan kelompok. }\end{array}$ & $\begin{array}{l}\text { Ditingkatkannya birokrasi dapat } \\
\text { menghabiskan uang masyarakat } \\
\text { dengan tidak proporsional }\end{array}$ \\
\hline $\begin{array}{l}\text { Pengeluaran yang rendah dalam } \\
\text { organisasi: untuk untuk sebuah } \\
\text { perluasan bergantung pada birokrasi } \\
\text { nasional. }\end{array}$ & $\begin{array}{l}\text { Sulit untuk membentuk identitas } \\
\text { bersama dikarenakan adanya } \\
\text { keberagaman budaya di ASEAN. }\end{array}$ \\
\hline $\begin{array}{l}\text { Kesadaran regional yang lebih baik } \\
\text { dalam negara anggota dan } \\
\text { masyarakatmya. }\end{array}$ & $\begin{array}{l}\text { Lemahnya hubungan antara integrasi } \\
\text { ekonomi dan masyarakat yang } \\
\text { diuntungkan dengan adanya hal } \\
\text { tersebut. }\end{array}$ \\
\hline
\end{tabular}

\section{Penutup}

\section{Kesimpulan}

Pembangunan sistem hukum ASEAN masih banyak kekurangan yang menyebabkan tidak efektif dan efisiennya kinerja kelembagaan dan mekanisme penyelesaian sengketa yang ada. Sebagai sebuah organisasi antar pemerintah, maka otoritas tertinggi dalam organisasi ialah pertemuan kepala negara/pemerintahan negara anggota ASEAN yang disebut sebagai ASEAN Summit. Sebagai lembaga yang memiliki

\footnotetext{
${ }^{48}$ Loffelholz, Martin and Danilo A. Arao, Ibid., hal. 10.
} 
otoritas tertinggi maka ASEAN Summit memiliki otoritas sebagai pembuat kebijakan (policy making). Prinsip dasar pengambilan keputusan dalam ASEAN adalah konsultasi dan konsensus yang menunjukkan bahwa ASEAN menganut bentuk hubungan antar negara yang berlandaskan pada prinsip kedaulatan penuh negara anggota. dengan adanya Piagam ASEAN menjadikan ASEAN sebagai sebuah rule-based organization.

Bahwa belum ada lembaga yang bersifat supranasional, dan tidak ada sentralisasi kewenangan dalam institusi ASEAN. Hal tersebut membuktikan bahwa ASEAN masih berlandaskan hukum internasional klasik dimana kedaulatan negara masih sangat mendominasi. Meskipun demikian, hal ini tidak menutup kemungkinan bagi ASEAN untuk menuju kearah sebagaimana Uni Eropa meskipun masih diperlukan banyak usaha dan kemauan dari anggotanya untuk mencapai suatu komunitas yang lebih terintegrasi.

ASEAN memiliki beragam mekanisme penyelesaian sengketa yang diatur tersendiri di setiap bidangnya, hal ini berbeda dengan WTO dan Uni Eropa yang memiliki satu mekanisme spesifik dan lembaga penyelesaian sengketanya. Namun demikian tidak terdapat suatu lembaga penyelesaian sengketa sehingga menjadi kendala dalam implementasi kebijakan ASEAN.

\section{Rekomendasi}

Dengan adanya tantangan dan kedala-kendala dalam mencapai integrasi lebih mendalam maka untuk mendorong ASEAN kearah pada suatu komunitas yang terintegrasi diperlukan adanya suatu dorongan dari masyarakatnya. Intergrasi atas kehendak masyarakat ASEAN dan tidak hanya dari negara. ${ }^{49}$ Integrasi ASEAN melalui ASEAN people, kesadaran masyarakat ASEAN untuk menjadi suatu komunitas sebagaiman tertuang dalam Preambule Piagam ASEAN, kesadaran untuk membentuk suatu masyarakat ASEAN yang madani (civil society) yang dicapai melalui fungsi promosi ${ }^{50}$ untuk memperkenalkan ASEAN dengan cara mengadakan pertemuan-pertemuan tingkat ASEAN yang dapat meliputi semua stakeholder ASEAN dalam semua lapisan.

Selain itu, ASEAN perlu melakukan pembangunan baik dalam institusi maupun mekanisme penyelesaian sengketa yang akan memperkuat keorganisasian ASEAN menuju suatu komunitas. Hal ini dapat dilakukan dengan mengadopsi sistem hukum baik dalam Uni Eropa dan WTO. ASEAN dapat menjadikan Uni Eropa dan WTO sebagai inspirasi namun bukanlah role model dalam pembentukan sistem hukum

\footnotetext{
${ }^{49}$ Wawancara Bapak Adijaya Yuruf dan Bapak Hadi Rahmat Purnama.

${ }^{50}$ Chen, Lung Chu, "An Introduction to Contemporary International Law, A Policy Oriented Perspective”, 2nd Edition, (London: Yale University Press, 2000), hal. 333.
} 
ASEAN. Dalam hal ini ASEAN harus mencari bentuk yang terbaik bagi komunitas ASEAN yang harus disesuaikan dengan kondisi ASEAN.

ASEAN sebagai penjelmaan kepentingan masing-masing anggotanya harus mengedepankan kepentingan bersama sehingga dapat terbentuk sistem hukum bersama yang mengakomodir kepentingan umum semua Negara anggota ASEAN. Meskipun ada perbedaan dalam sistem hukum di masing-masing Negara ASEAN namun tidak menutup kemungkinan adanya harmonisasi hukum dan bahkan unifikasi hukum di ASEAN seperti halnya unifikasi hukum dalam perlindungan hak asasi manusia melalui misalnya adopsi suatu Konvensi mengenai hak asasi manusia di ASEAN (ASEAN Convention on Human Rights) dan untuk penyelesaian sengketa ada baiknya dibentuk suatu pengadilan di tingkat ASEAN khususnya untuk hal-hal yang bersifat umum dan universal sebagaimana yang telah dibentuk di Uni Eropa yaitu "European Court on Human Rights". 


\section{Daftar Pustaka}

\section{Buku}

Adolf, Huala. Hukum Perdagangan Internasional, Jakarta: Rajawali Press, 2006.

AK, Syahmin. Hukum Dagang Internasional dalam Kerangka Studi Analitis, Jakarta: Rajawali Press, 2005.

Arifin, Sjamsul et. al., Masyarakat Ekonomi ASEAN 2010, Jakarta: Penerbit Elex Media Komputindo, 2008.

ASEAN National Secretariat of Indonesia, ASEAN NonGovernmental/Private Organizations, Jakarta: ASEAN National Secretariat of Indonesia, 1977

Aust, Anthony, Modern Treaty Law and Practice, Edisi ke-2. Cambridge: Cambridge University Press, 2002.

Baudelle, Guy. et. al., Le Projet européen Histoire, enjeux, prospective, Rennes: Les Pur Presses Universiataires De Rennes, 2004.

Beaupré, Nicholas dan Caroline Moine. L'Europe de Versailles à Maastricht Visions, moments et acteurs des projets européens, Paris: Seli arslan, 2007.

Borchardt, Klaus-Dieter, $L^{\prime} A B C$ du Droit Communautaire, Brussels: Commission europeenne, 2000.

- L'ABC du Droit Communautaire, Brussels: Commission europeenne, 2010.

Bourrinet, Jacques. Droits Nationaux, Droit Communautaire: Influences Croisees, Paris: Centres d'Etudes et de Recherches Internationales et Communautaires, 2000.

Cafruny, Alan W dan Rosenthal G Glenda. The State of the European Community The Maastricht Debates and Beyond, Colorado: Lynne Rienner Publisher, 1993.

Carreau, Dominique. Droit International, Edisi ke-9, Paris: Pedone, 2007 ,

Cambridge University Press. The Legal Texts The Results of the Uruguay Round of Multilateral Trade Negotiations, Cambridge University Press, 2005.

Cini, Michelle. European Union Politics, Edisi-1, Oxford: Oxford University Press, 2003.

Collins, Lawrence. European Community Law in the United Kingdom, Edisi ke-4, London: Butterworths \& co Publishers, 1990. 
Combacau, Jean dan Serge Sur. Droit International Public, Edisi ke-7, Paris: Montchrestien, 2006.

Conrad, R. Christiane. Processes and Production Methods (PPMs) in WTO Law Interfacing Trade and Social Goals, United Kingdom: Cambridge University Press, 2011.

Courty, Guillaume dan Guillaume Devin. La Construction Europeenne, Paris: La Découverte, 2005.

CPF, Luhulima. ASEAN Menuju Postur Baru, Jakarta: Center For Strategic And International Studies, 1997.

Daillier, Patrick, Mathias Forteau dan Alain Pellet. Droit International Public. Edisi ke-8, Paris: L.G.D.J, 2009.

Dam, Sjamsumar dan Riswandi. Kerjasama ASEAN Latar Belakang, Perkembangan, dan Masa Depan, Jakarta: Ghalia Indonesia, 1996.

De Cruz, Peter. Perbandingan Sistem Hukum Commow Law, Civil Law dan Socialist Law, Diterjemahkan oleh Narulita Yusron. Cetakan 1. Jakarta: Penerbit Nusa Media, 2010.

D. Mitchell, Andrew. Legal Principles in WTO Disputes, New York: Cambridge University Press, 2008.

Fawcett, Louise dan Andrew Hurrel. Regionalism in World Politics. Amerika Serikat: Oxford University Press, tanpa tahun.

Ferréol, Gilles. et. al., Dictionnaire de l'Union européenne, Paris: Armand Colin, 2000.

Gautron, Jean-Claude. Droit Européen, edisi ke-11, Paris: Dalloz, 2004.

Griffifths, Martin dan Terry O'Callaghan.2002. International Relation: The Key Concepts, New York: Routledge, 2002.

Hen, Christian dan Jacques Leonard. L'Union Européenne, edisi ke-8, Paris: La Découverte, 2000.

Hohmann, Harald Ed. Agreeing and Implementing the Doha Round of the WTO, United Kingdom: Cambridge University Press, 2008.

H. Jackson, John. Sovereignty, the WTO, and Changing Fundamentals of International Law, New York: Cambridge University Press, 2006.

. The World Trading System Law and Policy of International Economic Relations, United States of America: MIT Press, 2001.

Isaac, Guy dan Marc Blanquet. Droit général de l'Union européenne, Edisi ke-9. Paris: Dalloz, 2006.

Jack L. Goldsmith dan Erica A. Posner. The Limits of International Law, New York: Oxford University Press, 2005. 
Jones, Walter S. (diterjemahkan oleh Dr. Budiono Kusumohamidjojo). Logika Hubungan Internasional: Kekuasaan, Ekonomi Politik Internasional dan Tantanan dunia 2, Jakarta: PT. Gramedia Pustaka Utama, tanpa tahun.

Juwana, Hikmahanto. Hukum Internasional Dalam Perspektif Indonesia sebagai Negara Berkembang, Jakarta: PT. Yarsif Wantampone, tanpa tahun.

Kaczorowska, Alina. European Union Law, Edisi kedua. New York: Routledge, 2011.

Kermarec, Bruno. L'UE et L'ASEAN Mondialisation et Intégrations régionales en Europe et en Asie, Dunkerque: L'Harmattan, 2003.

Kusumaatmadja, Mochtar dan Etty R. Agoes. Pengantar Hukum Internasional, Edisi ke-2. Bandung: Penerbit P.T Alumni,2003.

Maidan Flores, Jamil. ASEAN : How It Works, Jakarta: ASEAN Secretariat, 2000.

Mamudji, Sri. et. al., Metode Penelitian dan Penulisan Hukum, Jakarta: Badan Penerbit Fakultas Hukum Universitas Indonesia, 2005.

Mendras, Henri. L'Europe des Européens, Paris: Editions Gallimard, 1997.

Ohmae, Kenichi. Hancurnya Negara-Bangsa Bangkitnya Negara-kawasan dan Geliat Ekonomi Regional Di Dunia Tak Terbatas, Cetakan ke2, Jakarta: Penerbit Qalam, 2010.

Pandika, Rusli. Sanksi Dagang Unilateral Di Bawah Sistem Hukum WTO, Bandung: Penerbit PT. Alumni, 2011.

Panizzon, Marizon. Nicole Pohl dan Pierre Sauve Ed. GATS and the Regulation of International Trade in Services, New York: Cambridge University Press, 2008.

Pierre Klein dan Philippe Sands. Bowett's Law of International Institutions, Edisi ke-5, London : Sweet \& Maxwell, 2001.

Roches, Jean-Jacques. Relations Internationales, Edisi ke- 3, Paris: Librairie Générale de Droit et de Jurisprudence, 2005.

Rudden, Bernard. Basic Community Cases, Oxford: Clarendon Press, 1987.

Ruzie, David. Droit International Public, Edisi ke-15, Paris: Dalloz, 2000.

Sampson, P Gary and W. radnee Chambers Ed. Developing Countries and the WTO, Tokyo: United Nations Press, 2008. 
S, Nuraeini, Deasy Silvya dn Arfin Sudirman. Regionalisme Dalam Studi Hubungan Internasional, Cetakan 1, Yogyakarta: Penerbit Pustaka Pelajar, 2010.

Shaw, Josephine. European Community Law, Malaysia: MacMillan Press LTD, 1993.

Sinclair, I M. The Vienna Convention On The Law Of Treaties, Manchester: Manchester University Press, 1973.

Soekanto, Soerjono. Pengantar Penelitian Hukum, Cetakan ke-3, Jakarta: Penerbit Universitas Indonesia, 2007.

Sood, Muhammad. Hukum Perdagangan Internasional, Jakarta: Rajawali Pers, 2011.

Suryokusumo, Sumaryo. Pengantar Hukum Organisasi Internasional, Cetakan ke-1, Jakarta: PT Tatanusa, 2007.

Suwardi, Sri Setianingsih. Pengantar Hukum Organisasi Internasional, Cetakan ke-1, Jakarta: Penerbit Universitas Indonesia, 2004.

Terrenoire, Alain. Le Parlement Européen Cet Inconnu, Edisi ke-1, Paris: Editeur le cherche midi,1994.

Thody, Philip. An Historical introduction to the European Union, Edisi ke-1, London: Routledge, 1997.

Than, Mya, ed. ASEAN Beyond the Regional Crisis Challenges and Initiatives, Singapura: Institute of Southeast Asian Studies, Singapore, 2001).

Tillotson, John dan Nigel Foster. Text, Cases, and Materials on European Union Law, Edisi 4, London: Cavendish Publishing Limited, 2003.

Van Den Bossche, Peter. The Law and Policy of the World Trade Organisation, Edisi kedua. New York: Cambridge University Press, 2008.

Daniar Natakusumah, dan Joseph Wira Koesnaidi, Pengantar Hukum WTO (World Trade Organization), Jakarta: Yayasan Obor Indonesia, 2010.

Verhoeven, Joe. Droit International Public, Brussel: L'arcier, 2000.

Weiler, J. H. H dan Marlene Wind. European Constitutionalism Beyond The State, New York: Cambridge University Press, 2003.

W, Schill, Stephan. The Multilateralization of International Investment Law, New York: Cambridge University Press, 2009. 


\section{Jurnal}

Anderson, James dan James Goodman. "Region, States and the European Union: Modernists Reaction or Postmodern Adaptation?", Review of International Political Economy, (Vol. 2, No. 4 1995): 600-631. $<$ http://www.jstor.org/stable/4177164>, diakses tanggal 23 Agustus 2010

Bellamy, Richard dan Dario Castiglione. "Building the Union: The Nature of Sovereignity in the Political Architecture of Europe", Law and Philosophy, (Vol. 16, No. 4, Juli 1997): 421-445, Constructing Legal Systems: "European Union in Legal Theory",. $<$ http://www.jstor.org/stable/3504983>, diakses tanggal 19 Agustus 2010

Bowles, Paul dan Brian MacLean. "Understanding Trade Bloc Formation: The Case of the ASEAN Free Trade Area", Review of International Political Economy (Vol. 3, No. 2, 1996): 319-348. $<$ http://www.jstor.org/stable/4177188>, diakses tanggal 19 Agustus 2010

Chalermpalanupap, Termsak. "ASEAN Secretariat and Legal Issues Arising from the ASEAN Charter", Indonesia Journal of International Law, ASEAN, (Volume 6 Nomor 2 Januari 2009): 178-186.

Davidson, J. Paul. "The ASEAN way and The Role of Law in ASEAN Economic Cooperation", Singapore Year Book of International Law and Contributors, 2004: 165-176.

De Beus, Jos. "Quasi-national European Identity and European Democracy", Law and Philosophy, (Vol. 20, No. 3, Mei 2001), Union Citizenship: 283-311. <http://www.jstor.org/stable/ 3505101>, diakses tanggal 23 Agustus 2010

Djafar, Zainuddin. "Piagam ASEAN, Legalitas Tonggak Baru Menuju Integrasi Regional?". Indonesia Journal of International Law, ASEAN, (Volume 6 Nomor 2 Januari 2009):. 197-215.

Grabbe, Heather. "European Union Conditionality and the Acquis communautaire", International Political Science Review, (Vol. 23 No. 3, Juli 2002) Enlarging the European Union : Challenges to and from central and Eastern Europe: 249-268. $<$ http://www.jstor.org/stable/1601310>, diakses tanggal 19 Agustus 2010.

Laurence Henry, Laurence. "The ASEAN Way and Community Integration", European Law Journal, Vol. 13, No. 6, November 2007: 857-879. 
Holman, Otto. "Asymmetrical Regulation and Multidimensional Governance in the European Union. Review of International Political Economy", (Vol 11, No. 4, October 2004) Global Regulation: 714-735, <http://www.jstor.org/stable/4177519>, diakses tanggal 23 Agustus 2010.

MacCormick, Neil. "Democracy, Subsidiarity, and Citizenship in the 'European Commonwealth", Law and Philosophy, (Vol. 16 No. 4, Juli 1997): 331-356, Constructing Legal Systems: "European Union" in Legal Theory, <http://www.jstor.org/stable/3504980>, diakses tanggal 19 Agustus 2010.

Mitrany, David. "The Functional Approach to World Organization. International Affairs (Royal Institute of International Affairs 1944)”, Vol. 24, No. 3. (Jul., 1948): 350-363. Jstor.

Oratmangun, Djauhari. "ASEAN Charter: A New Beginning for Southeast Asian Nations", ASEAN, Indonesia Journal of International Law (Volume 6 Nomor 2 Januari 2009): 196.

Simon, Sheldon. "ASEAN and Multilateralism, The Long Bumpy Road to Community", Contemporary Southeast Asia: A Journal of International and Strategic Affairs, Volume 30, Number 2, August 2008: 264-292.

Van Roermund, Bert. "Jurisprudential Dilemmas of European Law", Law and Philosophy, (Vol. 16, No. 4, Juli 1997): 357-376, Constructing Legal Systems: European Union in Legal Theory. $<$ http://www.jstor.org/stable/3504981>, diakses tanggal 19 Agustus 2010.

\section{Skripsi}

Ausiandra, Yusuf. "Perbandingan Antara Sistem Hukum Regional Uni Eropa Dengan Kerjasama Hukum Regional ASEAN". Diuji pada tanggal 3 Januari 2011 di Depok dalam rangka memperoleh gelar sarjana hukum dari Universitas Indonesia.

\section{Perjanjian Internasional}

ASEAN Charter, 2007.

GATT (General Agreement on Tariff and Trade), 1989.

Marrakesh Agreement Establishing the World trade Organization and Annexes, 1994.

Traité de Lisbonne 2009 (Terdiri atas: Traité sur l'Union Européenne atau TUE dan Traité sur le Fonctionnement de l'Union Européenne atau TFUE). 